\title{
Effect of Capital Structure on Firm's Profitability (Evidence from Endowment Fund for Rehabilitation of Tigray /EFFORT/Manufacturing Companies)
}

\author{
Tefera Balcha Bedada \\ Head, Department of Accounting and Finance, College of Business and Economics \\ Madda Walabu University, Ethiopia
}

\begin{abstract}
Capital structure the mix of securities and the proportionate sums that make up capitalization. It is the combination of unlike sources of long-term sources such as equity shares, preference shares, debentures, long-term loans and retained earnings. The term capital structure refers to the link between the various long-term sources financing such as equity capital, preference share capital and debt capital. This research was done to assess the effect of capital structure on profitability of EFFORT manufacturing companies. The researcher used secondary sources of data, which is audited financial statements such as balance sheet and income statement of eight (8) manufacturing companies from period of 2008 to 2017. The companies selected are those operated for at least 10 years. Because of this all selected samples are aged in the operation more than ten (10) years. For this study panel data of eight (8) manufacturing firms for ten (10) years from (2008 to 2017) is used. Independent variables used for this study were total debt to total asset, total debt to equity, and Long-term debt to total assets and dependent variable were return on assets, and also control variables were firm size, sales growth rate and tangibility. Under this study descriptive statistics and correlation analysis were employed. For panel data regression, random effects regression was used for the data analysis. The result of the study shows that total debt to assets (TDA) and Long term debt to total assets (LTDA) are negatively significant with profitability of the firm and total debt to equity (TDE) is positively significant with profitability of the firm. As the result shows most of EFFORT manufacturing firms' use debt financing. The researcher recommends that for all managers of EFFORT manufacturing companies' equity source of finance is more profitable than debt financing.
\end{abstract}

Keywords: capital structure, profitability, returns on assets, total debt to assets, Long term debt to total assets, and total debt to equity.

DOI: $10.7176 /$ RJFA/11-7-05

Publication date: April $30^{\text {th }} 2020$

\section{Introduction}

Capital structure the mix of securities and the proportionate sums that make up capitalization. It is the combination of unlike sources of long-term sources such as equity shares, preference shares, debentures, long-term loans and retained earnings. The term capital structure refers to the link between the various long-term sources financing such as equity capital, preference share capital and debt capital. Deciding the appropriate capital structure is the important decision of the financial management because it is closely related to the value of the firm. Capital structure is the permanent financing of the company represented primarily by long-term debt and equity (Paramasivan C. and Subramanian T. 2009). Moyer, Guigan and Kretlow (2006) are defined capital structure as the amount of long-term debt, preferred stock, and common equity used to finance a firm.

The mix of debt and equity constitutes the capital structure of the firm (Brealey et al, 2008). According to Antwi et al. (2012) therefore posited that a firm should target maximizing its value by assessing how its capital structure or financial leverage is made up and how that debt equity composition impact on the value of the firm.

The theory of business finance in a contemporary starts with the Modigliani and Miller (1958) capital structure irrelevance proposition. The investor can generate any leverage that was wanted but not offered, or the investor can get rid of any leverage that the firm took on but was not wanted. As a result, the leverage of the firm has no result on the market value of the firm. The primary objective of this study is to investigate the effect of capital structure on profitability of EFFORT manufacturing companies from the time period of 2008 to 2017.

\section{Statement of the Problem}

Capital structure is playing the great role on companies' profitability. The successful selection of capital structure in the organization is fundamental for maximizing their wealth. Empirical studies were undertaken contradictory with respect to country, industry, size of the firm and also type of corporate debt utilized. The choice of capital structure is one of the most important strategic financial decisions of organization. Most studies found that there is a negative relationship between profitability and debt but Kim et al. (2014) indicated that the overall capital structure has no significant impact on profitability, neither at an industry level nor at a firm level. One of interesting findings by Paolo (2010) indicates profitability is positively and significantly associated with revolving credit and 
term loans.

In addition, Babatunde (2014) investigated the relationship between capital structure and profitability on Nigeria stock exchange. The study established that highly leveraged firms are more profitable since there is a significant relationship in almost all firms between return on equity and debt to equity. After going through extensive research on international data, Rajan and Zingales (1995) failed to conclude and suggested further research is required with more detailed data to identify more accurate proxies meanwhile; theoretical underpinnings of the observed correlation are still largely remain unresolved. For undertaking their operations all manufacturing companies required capital (fund). These capitals may come from shareholder by issuing share to the public or through external party by making debt. The summation of shareholders fund (equity) and external liability is named as capital structure.

In Ethiopia Frezewd (2016) studied on corporate capital structure and its impact on Profitability in manufacturing share companies. According to his study, established significant and positive relationship between short-term liabilities to total liabilities ratio, long-term debt capitalization ratio and interest coverage ratio with profitability.

As to the researcher's knowledge there are perhaps no previous researches in Tigray which investigated the effect of capital structure variables and profitability rigorously on Endowment Fund for Rehabilitation of Tigray manufacturing companies.

Though, there are some studies in relation to the topic such as Kibrom M (2010), Aregaw (2015) and Frezewd (2016) which were made on impact of capital structure and determinants of capital structure on commercial banks.

However, this study emphasizes on the effect of capital structure on the profitability of EFFORT manufacturing companies. This capital structure area needs a strong attention on the study how capital structures are affects the profitability of the firms.

\section{Objectives of the Study}

The general objective of this study was to investigate the effect of capital structure on profitability of EFFORT manufacturing companies.

Specifically the study has the following objectives:

$\checkmark$ To investigate the effect of total debt ratio on profitability of EFFORT manufacturing companies.

$\checkmark$ To determine the relationship between total debt to equity ratio and profitability of EFFORT manufacturing companies.

$\checkmark \quad$ To determine the link between long-term debt ratio and profitability of EFFORT manufacturing companies.

\section{Hypotheses of the Study}

To achieve the objectives of this study the following hypotheses were tested. The pecking order theory of Myers and Majluf (1984) argues in the contrary of static trade-off theory. It advocates also that the firm will borrow, rather than issuing equity, when internal cash flow is not sufficient to fund capital expenditures.

H1: There is no significant relationship between total debt to asset and profitability of EFFORT manufacturing companies.

H2: There is no significant relationship between total debt to equity and profitability of EFFORT manufacturing companies.

H3: There is no significant relationship between Long-term debt ratio and profitability of EFFORT manufacturing companies.

\section{Review of Related Literature}

According to the definition of James C. Van Horne (2009) defined that capital structure is the mix of a firm's permanent long-term financing represented by debt, preferred stock, and common stock equity. According to the definition of Presanna Chandra (2009) capital structure is the composition of a firm's financing consists of equity, preference, and debt.

Modigliani and Miller (1958) established what has been known as the theoretical principles underlying the combination of debt equity mix or the capital structure of a firm. Theories on capital structure have been proposed by researchers and scholars of the subject. Ross (2003) states that a corporation can raise money (cash) from lenders or from shareholders. If it borrows, the lenders contribute the cash, and the corporation promises to pay back the debt plus a fixed rate of interest. The financial manager needs to identify the risks and make sure they are managed properly. For example, debt has its advantages, but too much debt can lead the company in bankruptcy (Brealey, Myers, \& Allen, 2011). Many of theories have been advanced in explaining the capital structure and profitability / value of firms. The existing theories of capital structures and profitability/ firm value are explained as follows. 


\section{Traditional Theories}

As mentioned on Keshar (2004); David Durand propounded the net income approach of capital structure in 1952. According to the 'traditional' theory of capital structure, the value of a company is dependent on the capital structure or gearing level and it will be on optimal level or, an optimal capital structure exists when the weighted average cost of capital is at a minimum limit and market value of the company at maximum.

\section{Modigliani and Miller (MM) theory}

In corporate finance theories, the formative work by Modigliani and Miller (1958) in capital structure provided a basis for the development of the theoretical framework within which various theories were about to transpire in the future. Modigliani and Miller (1958) concluded to the broadly known theory of "capital structure irrelevance" where financial leverage does not affect the firm's value.

\section{The Signaling, or Asymmetric Information Theory}

The signaling, or asymmetry information theory was proposed by Myers and Majluf (1984) when they contended that equity is a less favored means to raise capital because when managers issue new equity, investors take it as a signal that the managers think that the firm is overvalued, so they are taking advantage of this over-valuation. As a result, investors will place a lower value to the new equity issuance. Asquith and Mullins (1983), Masulis and Korwar (1986) empirically observed that announcements of new equity issues are greeted by sharp declines in stock prices.

\section{The Market Timing Theory}

This theory expresses that the present capital structure of a firm is the collective outcome of past attempts to time the equity market. Market timing means that firms will issue new shares when they see the stocks to be overvalued and that firms repurchase their own shares when they consider them to be undervalued accordingly, the current capital structure is unequivocally linked to historical market values (Baker \& Wurgler, 2002). According to Gatsi \& Akoto (2010) managers should critically study the capital market and exploit the information asymmetry that exist and only issue new shares when they trust that those shares are overpriced by the market and vice versa.

\section{Dynamic Trade-Off Theory}

Dynamic trade-off theory can be traced back to Fischer, Heinkel and Zechner (1989), FHZ, who was one of the first to develop a model in which companies may deviate from their optimal capital structure. The increasing dissatisfaction with the static trade-off model has led to many contributions to dynamic trade-off theory since the Fischer, Heinkel and Zechner's paper, especially within the last ten years.

\section{Empirical Studies}

To achieve target profit it is agreeable that companies must empower all of its resources optimally. The problem rise when the resource is insufficient; and companies decide to obtain debt with consideration of profitability and risk of bankruptcy. (Mohammad et al, 2012) seeks to extend, Abor's (2005), and Gill, et al. (2011) verdicts regarding the effect of capital structure on profitability by examining the effect of capital structure on profitability of the industrial companies listed on Amman Stock Exchange during a six year retro (2004-2009). Applying correlations and multiple regression analysis, the results reveal significantly negative relation between debt of the companies and profitability. Related studies such as (Winston Pontoh, 2013), (Koech, 2013), (Singh, 2013) and (Opoku et al, 2014) reaffirmed this result.

In addition, Singh (2013) analyzed how distant capital structure affects the profitability of corporate firms in India. The study tried to establish the hypothesized relationship as to how far the capital structure affect the business revenue of firms and what the interrelationship is between capital structure and Profitability. The study proved that there has been a strong relationship between capital structure variables and Profitability variables, return on assets (ROA) and Return on capital Employed (ROCE). The capital structure found to have significant influence on Profitability, and increase in use of debt fund in capital structure tends to minimize the net profit of the Manufacturing firms listed in Bombay Stock Exchange in India.

On the other hand, Babatunde Yusuf et al. (2014) investigated the relationship between capital structure and profitability of conglomerate, consumer goods, and financial services firms on quoted firms in Nigeria stock exchange. The study established a significant relationship in almost all firms between return on equity and debt to equity which justifies highly geared firms are more profitable. Moreover, they posit the nature of the industry also determines the effect of capital structure on profitability.

As to the access and knowledge of the researcher the impact of capital structure on profitability of various Ethiopian industries is still under-explored area in literature of financing decision and manufacturing industry is not an exception. Though, there are some studies in relation to the topic such as Mekonnen (2011), Ashenafi (2005) and Mintesinot (2010) which were made on determinants of capital structure. They fail to show us the possible 
inverse relationship i.e. not only how profitability affect capital structure but also the impact of capital structure on profitability.

The empirical study on long term debt is a component in the capital structure of a firm, yet it has to be applied with a lot of caution. Prior studies on long term debt have offered varied results on the effects of Long term debt on financial performance. Ebaid (2009) in his study on the emerging market economy of Egypt found that long term debt has a negative effect on return on asset. Huang and Song (2006) found that a long term debt has a negative effect on profitability as measured by the return on assets. Some researchers found that long term debt has a positive effect on financial performance such as Abor (2005). While others found that long term debt has a negative effect on financial performance such as Ebaid (2009); Huang and Song (2006), presents conflicting results on this important element of capital structure leading to a gap in knowledge for further research. Generally the above all empirical studies have its own limitation. However the researcher tries to undertake the limitations of the study.

Research Methodology and Data Analysis

The purposes of the study were to assess the effect of capital structure on profitability of EFFORT manufacturing companies. Under methodology part the researcher lists the research design, the study population, source of the data, study period and it also specifies model uses for the regression analysis. The sample of the study concentrated only on EFFORT manufacturing companies which have been operating at least ten (10) years, because the data used for this study is audited financial statement for ten (10) years.

Variables description

\begin{tabular}{|l|l|}
\hline \multirow{2}{*}{ Independent Variables } & Total debt to total asset ratio \\
\cline { 2 - 2 } & Total debt to equity ratio \\
\cline { 2 - 2 } & Lon-Term debt ratio \\
\hline \multirow{2}{*}{ Dependent Variables } & Return on asset (ROA) \\
\hline & Firm Size \\
\cline { 2 - 2 } & Sale growth rate \\
\cline { 2 - 2 } & Tangibility \\
\hline
\end{tabular}

\section{Model Specification}

As mentioned above, the effect of capital structure on firm's performance was estimated by using similar quantitative models.

The general formula used for the model is:

Profit $=\mathrm{f}($ capital structure $)$

$\mathrm{Y}_{\text {it }}=\beta 0+\Sigma \beta X \mathrm{it}+\varepsilon$

$\mathrm{ROA}=\beta_{0}+\beta_{1}(\mathrm{TDA})+\beta_{2}(\mathrm{TDE})+\beta_{3}(\mathrm{LTD})+\beta_{4}(\mathrm{FS})+\beta_{5}(\mathrm{SGR})+\beta_{6}(\mathrm{TN})+\varepsilon$

A histogram of residuals is a simple graphic device that is used to learn something about the shape of variable. It is always a good practice to plot the histogram of the residuals as a rough and ready method of testing for the normality assumption (Gujarati, 2004).

Correlation Matrix in between dependent variable and independent variables

\begin{tabular}{r|rrrrrrr} 
& roa & tda & td & ltda & fs & sgr & tn \\
\hline raa & 1.0000 & & & & & & \\
tda & -0.6467 & 1.0000 & & & & & \\
td & 0.3336 & -0.3525 & 1.0000 & & & & \\
1tda & -0.6326 & 0.8492 & -0.3452 & 1.0000 & & & \\
fs & 0.3765 & 0.0802 & -0.0475 & 0.0223 & 1.0000 & & \\
sgr & 0.2080 & -0.0540 & -0.0010 & -0.0398 & 0.0785 & 1.0000 & \\
tn & -0.3738 & 0.1949 & 0.0306 & 0.1984 & -0.0834 & -0.1299 & 1.0000
\end{tabular}

Source: Researcher's own computation based on financial statements of the firm.

The correlation coefficient is a measure of linear relationship between two variables. Correlation is used to measure the direction of the linear connection between two variables as well as to measure the strength of association between variables (Tabachnick \& Fidell, 2007).

The correlation matrix in the above table shows that the dependent variable return on asset ratio (ROA) is negatively correlated at -0.6467 with total debt to asses, at -0.6326 with long-term debt to asset and at -0.3738 with tangibility. In other hands the dependent variables return on asset ratio (ROA) is positively correlated at 
0.3336 with total debt to equity, at 0.3765 with firm size and at 0.2080 with sales growth rate. This implies that equity, firm size and sales growth rate makes companies as profitable. As shown on correlation matrix of the above table, total debt to asset is negatively correlated with total debt to equity and sales growth rate. Total debt to equity is also negatively correlated with long term debt to asset, firm size and sales growth rate. In other word total debt to asset is positively correlated with long term debt to asset, firm size and tangibility.

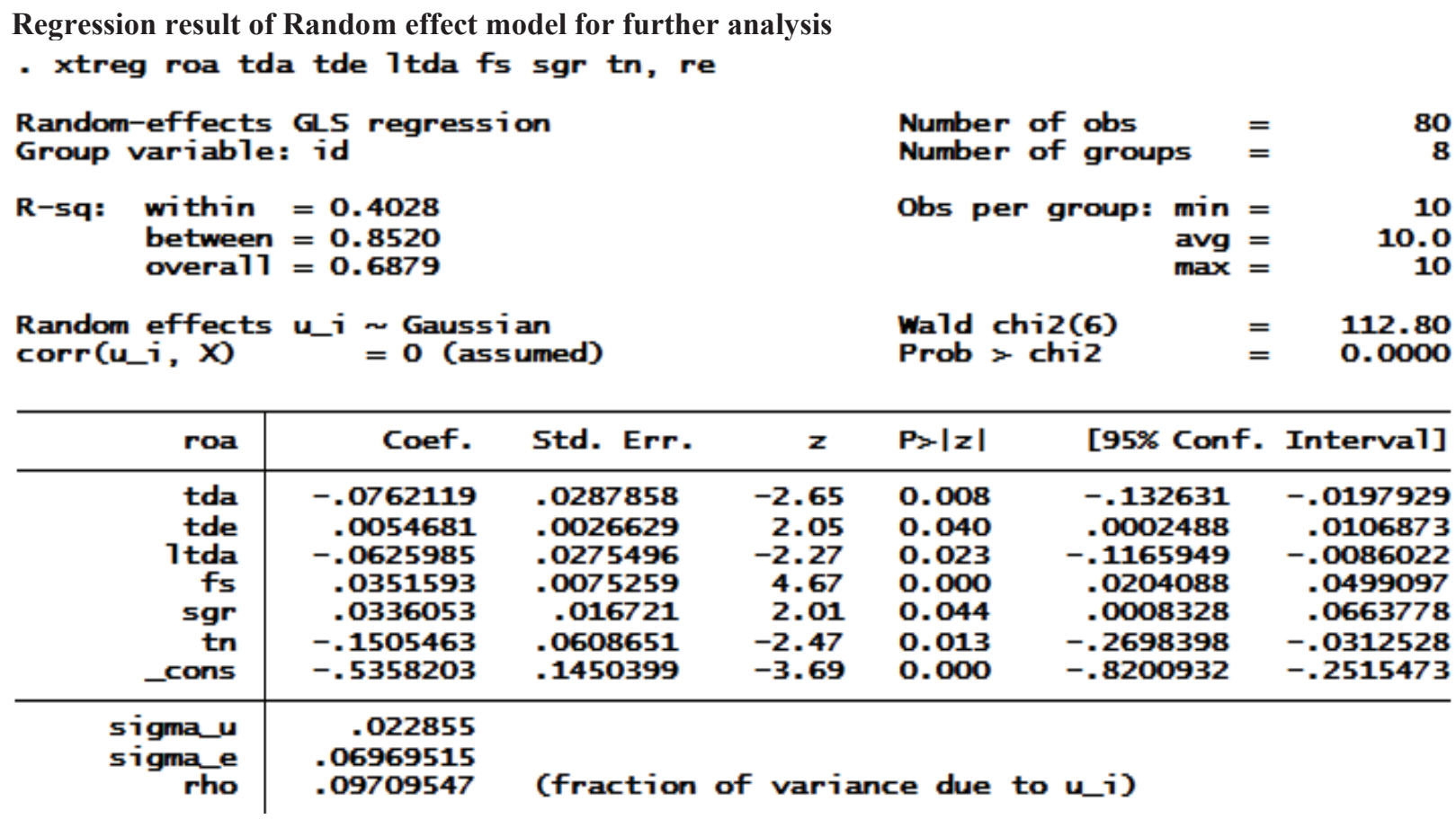

Source: Researcher's own computation based on financial statements of the firm.

The above table shows p-value is zero, which is the data is fitted with the model. In this model all independent and control variables are significant. The p-value show that the explanatory variables i.e. total debt to asset, total debt to equity, long term debt to asset, firm size, sales growth rate and tangibility appear to be significant. Total debts to asset and Firm size are significant at 1 percent significance level and the remaining total debt to equity, long term debt to total asset, sales growth rate and tangibility are significant at 5 percent significance level.

\section{Conclusion and Recommendation}

This study was conducted to investigate the effect of capital structure on profitability of EFFORT manufacturing companies. The researcher used panel data regression model to achieve the objective of the study. For this study panel data of eight (8) manufacturing companies for ten (10) years from 2008 to 2017 was used. Using data collected from audited financial statements, regression analysis was conducted to test hypothesis which were developed based on literature. The study used ROA as dependent variable and TAD, TDE, LTDA, FS, SGR and TN as independent variables.

Capital structure was measured by total debt to assets, total debt to equity and long term debt to assets ratio. The result of regression analysis showed the total debt to asset and long term debt to asset ratio have negative relationship with profitability. However, the link between debt equity ratio and profitability is positively related. Therefore, the study has refuted all the three hypotheses. Hence, EFFORT manufacturing companies can increase their profitability increasing its debt to equity ratio, or by decreasing either the debt to assets ratio or long term debt to assets ratio. Therefore, capital structure decisions are important for profitability of EFFORT manufacturing companies.

The study has shown a clear understanding of capital structure components which are total debt to asset, total debt to equity, and long term debt to asset and they influence firms' performance. Total debt to assets and long term debt to asset has a negative relationship on profitability measurement variable (return on assets) and also total debt to equity is positive relationship but their performance is very low. This result helps to the managers of EFFORT manufacturing companies to improve their firms' performance which can be done through appropriate capital structure components. Thus, management should be initiatives to encourage the firms' financial resources more on equity sources finance. Equity finance is better for firms' profitability rather than debt financing. Therefore, the recommendations of the study to the EFFORT manufacturing firm' from the findings are as follows: Total debt to assets is a negative significant relationship on profitability's of EFFORT manufacturing 
companies. To recommend for the firms that, it is advisable to use equity and retained earnings source of finance rather than debt financing to increase profitability's of the firm. When firms' use debt financing rather than equity source of finance it incurs loss by 0.0762 birr as 1 birr debt increase. However the result of this study is consistent with the pecking order theory that suggests profitable firms prefer own financing rather than debt financing. Therefore to maximize share holders wealth the managers of EFFORT manufacturing companies must be focus on equity of finance.

Total debt to equity is a positive significant relationship on profitability's of EFFORT manufacturing companies. Even though the relationship is positive the level of maximizing profit is very low. The researcher recommended that it is better when the firms' must depend on equity source of finance.

Long term debt to assets is a negative significant relationship on profitability's of EFFORT manufacturing companies. To recommend for the firms that, it is advisable to use equity source of finance rather than debt financing to increase profitability's of the firm, because long term debt have high interest rate. When a firm uses long term debt of finance rather than equity source of finance, its loss is increased by 0.0626 birr as 1 birr long term debt increased. This result is similar to the above result which is total debt to asset. However as indicated on the above the result of this study also consistent with the pecking order theory that suggests profitable firms prefer internal financing rather than external financing. Therefore to maximize share holders wealth the managers of EFFORT manufacturing companies should focus on equity source of finance rather than debt source of finance.

Generally as the result of the study, researcher recommend for all managers of EFFORT manufacturing companies' equity source of finance is more profitable than debt source of finance.

\section{References}

Abor, J. (2005). The effect of capital structure on profitability: an empirical analysis of listed firms in Ghana. The Journal of Risk Finance, 6(5), 438 - 445.

Antwi, S., Mills, E. F. E A. and Zhao, X. (2012). Capital Structure and Firms Value: Empirical Evidence from Ghana. International Journal of Business and Social Science. Vol 3 No 22.

Aregaw H. (2015). The impact of capital structure on profitability of commercial banks in Ethiopia

Ashenafi, B. (2005). Determinants of Capital Structure in Medium Enterprises in Ethiopia, Addis Ababa: AAU.

Asquith, P. and Mullins, D .W. (1983). The impact of initiating dividend payments on shareholders ${ }^{\text {ee }}$ wealth. Journal of Business: 77-96.

Babatunde, Y. K. I. Y. S. \&. A. O. (2014). Capital Structure and Profitability of Quoted Firms; the Nigerian Perspective (2000-2011).

Baker, M. and Wurgler, J. (2002). Market Timing and Capital Structure. The Journal of Finance 57, 1-32.

Brealey, R. A., Myers, S. C. and Allen, F. (2008). Principles of Corporate Finance. 9thEdition. McGraw-Hill International Edition.

Brealey, R. A., Myers, S. C., \& Allen, F. (2011). Financing Decisions. In Principles of Corporate Finance. New York, NY, McGraw-Hill/Irwin.

Ebaid I. E. (2009), The Impact of Capital Structure choice on Firm Performance: Empirical Evidence from Egypt. The Journal of Risk Finance. 2009; 10(5):477-487.

Fischer, E. O., Heinkel, R. \& Zechner, J. (1989). Dynamic Capital Structure Choice: Theory and Tests. The Journal of Finance, 44(1), 19-40.

Frezewd B. (2016). Corporate Capital Structure and Its Impact on Profitability: Evidence from Manufacturing Firms in Ethiopia

Gatsi, J. G. and Akoto, R. K. (2010). Capital Structure and Profitability in Ghanaian Banks. SSRN: http://ssrn.com/abstract $=1618952$

Gill, A, Biger, N. and Mathur, N. (2011). The effect of capital structure on profitability: Evidence from the United States. International Journal of Management, Vol. 28, No. 4, Part 1, pp. 3-15.

Gujarati, D. N. (2004). Basic Econometrics. 4th Edition, Mc Graw-Hill companies.

Harris, M and Raviv, A. (1991). The theory of capital structure, Journal of Finance 46, 297-356.

Huang G, Song FM. (2006). "The determinants of capital structure: Evidence from China". China Economic Review; 17(1):14-36.

James C. Van Horne (2009). Financial management ${ }^{e e}$, Published by New Age

Keshar, J. B. P. (2004). Determinants of Capital Structure: A Case Study of Listed Companies of Napal. The Journal of Nepalese Business Studies, 1(1).

Kibrom M. (2010). Determinants of capital structure: evidence from commercial banks in Ethiopia

Kim Abildgren, M. N. C. M. \&. O. (2014). Corporate Capital Structure and Profitability, Productivity and Access to Finance. Denish National Bank Working Paper, Volume 91.

Koech, S. K. (2013). The effect of Capital Structure on Profitability of Financial Firms Listed at Nairobi Stock Exchange, Nairobi: Kenyatta University. 
Masulis, R.W. \& Korwar, A. N. (1986). Seasoned equity offerings. Journal of Financial Economics (January): 91-118.

Mekonnen, A. (2011). The Determinants of Capital Structure Evidence from Manufacturing Share Companies of Addis Ababa, Addis Ababa: AAU.

Mintesinot, A. (2010). Determinants of Capital Structure, Evidence from Selected Manufacturing Private Limited Companies of Tigray Region, Mekelle: Mekelle University.

Modigliani, F. \& Miller, M. (1958). The cost of capital, corporate finance and the theory of investment. American Economic Review, 48, 261-297.

Moyer, Mc guigan, Kretlow. (2006). Contemporary Financial Management $10_{\text {th }}$ edition

Myers, S. C. (1984). The Capital Structure Puzzle. The Journal of Finance, 39(3), 575-592.

Paolo Colla, F. I. K. L. (2010). Debt Structure and Debt Specialization. lisben, s.n.

Paramasivan C. \& Subramanian T. (2009) financial management. Published by New Age International (P) Ltd., Publishers.

Presanna Chandra (2009). Financial management", Published by New Age

Rajan, R. G. \& Zingales, L. (1995). What Do We Know about Capital Structure? Some Evidence from International data. The Journal of Finance, 50(5), 1421-1460.

Ross, W. J. (2003). Capital Structure. In Corporate Finance, 6th edition. USA: McGraw-Hill/Irwin.

Singh, P. G. (2013). Interrelationship between Capital Structure and Profitability with Special Reference to Manufacturing Industry in India. International Journal of Management and Social Sciences Research, 2(8), 55-61.

Tabachnick, B.G. \& Fidell, L.S. (2007). Using Multivariate Statistics. 5th edition.

Winston Pontoh, V. I. (2013). Determinant Capital Structure and Profitability Impact (Study of Listed Company in Indonesian Stock Exchange). Research Journal of Finance and Accounting, 4(15), 43-50. 